\title{
Technostress and Performance of Auditing Firms in Nigeria
}

\author{
Omoneye 0. Olasanmi \\ Department of Management and Accounting, Obafemi Awolowo University, Ile-Ife, Nigeria \\ Email:neyeolasanmi@yahoo.com
}

How to cite this paper: Olasanmi, O.O. (2016) Technostress and Performance of Auditing Firms in Nigeria. Open Journal of Business and Management, 4, 799-819. http://dx.doi.org/10.4236/ojbm.2016.44077

Received: June 14, 2016

Accepted: October 28, 2016

Published: October 31, 2016

Copyright (@) 2016 by author and Scientific Research Publishing Inc. This work is licensed under the Creative Commons Attribution International License (CC BY 4.0).

http://creativecommons.org/licenses/by/4.0/

(c) (†) Open Access

\begin{abstract}
This study examined the level of technostress experienced among Nigerian auditors. It also identified the strategies adopted by workers of audit firms to cope with technostress. This was with a view to determine the effects of technostress on the performance of auditors. The study relied on primary data derived from the administration of questionnaire on auditors of four auditing firms in Nigeria. Simple random sampling technique was used in selecting a sample fraction of $50 \%$ from each of the selected firms. Thus, 825 out of 1650 population were identified for this study. Data collected were analyzed using appropriate descriptive and inferential statistical tools. The results showed that the level of technostress experienced by auditors on the whole was on the moderate side (47.8\%), in spite of their dependence on technological facilities. However, it was observed that some individual auditors experienced high technostress level in terms of slow computer speed (86.7\%), slow internet connection (84.5\%), total network failure (79.0\%), and meeting up with deadlines (57.1\%). In order to cope effectively with technostress on individual's levels, respondents suggested the provision of adequate training for employees before the introduction of any new technological facility, which was acclaimed by $94.9 \%$ of the respondents. The result of this study further showed that the less the level of technostress, the higher the performance among individual auditors, although, there was no significant relationship between technostress and performance $\left(\chi^{2}=1.690 ; \mathrm{p}=0.430\right)$ at the organizational level. The study concluded that given the pace of change and innovations in technology, the auditor's job might be a very stressful one with demands and changes to grapple with. It is thus crucial that auditors and their management system appreciate the different responses to technology use, as well as fashion out adaptable ways of adjusting to it.
\end{abstract}

\section{Keywords}

Technostress, Auditing, Performance 


\section{Introduction}

Technology has become an essential part in today's society. The advancement in technology has also been a dominant force in improving and enhancing organizational services. These rapid advances and changes in technology have caused many organizations to introduce employees to updated technology and software programs several times each year. This is often done in an attempt to stay technologically current. However, these frequent changes in technology have made employees work at paces they are barely able to sustain [1]. Rapid growth in technology and its extensive use in business and industry have increased competition among organizations across the globe. These compelling forces within organizations are continuously reshaping business strategies, restructuring hierarchy, re-engineering business processes, and altering managerial practices, thereby, forcing organizations to adapt innovative business models with a unique blend of technology [2]. Technology has changed the world into "an instant world" where things need to be done at a faster pace and electronic communications need to be responded to promptly. As technology is usually seen as a tool that improves efficiency, workers are expected to increase their output and to do more with less human effort [3]. This combination in the work environment however exacts a human price in the form of technostress, which is stress associated with the usage of technology. Thus, technology has indirectly added to notable stressors in the work environment.

Organizational use of information and communications technologies (ICTs) has become complex, real-time, ubiquitous, and pervasive, often requiring users to process information simultaneously and continually from different applications and devices. Consequently, information and communications technology (ICT) users deal with a workload of information, experience frequent interruptions from different computing devices and applications, and engage in multitasking on the devices. At times, they are increasingly frustrated and overwhelmed by continual efforts required in mastering the frequent introduction of new ICT facilities and as a result, in recent times, workers have experienced negative attitudes toward the usage ICT in the delivery of time-dependent tasks [4]. The usage of computer integrated systems, multiple databases, the Internet, the World Wide Web, and the rapid changes in information technology have also caused an enormous amount of strain on the users of such technologies [3].

Recent academic literatures have encapsulated these developments in the concept of technostress which is the state of feeling stressful as a result of being exposed to too much or being too dependent on technology [5]-[9]. Technostress describes the stress that users experience as a result of application multitasking, constant connectivity, information overload, frequent system upgrades and consequent uncertainty, continual re-learning and consequent job-related insecurities, and technical problems associated with the organizational use of ICT [10]. Laudon and Laudon [11] defined technostress as "stress induced by computer use". According to Rosen and Weil [12], resistant and hesitant technology users exist in every level of an organization. These users claim that technology has brought additional stress to their lives as a result of spending more time at computer systems to perform repetitive or administrative tasks. 
Technostress is a common workplace problem experienced by all professionals irrespective of their nature of work; however, this phenomenon is more common in situations that are deadline-driven [2]. Different firms are often affected profoundly by this challenge, and professionals serving these organizations are often observed under huge stress because the heavy burden of work does not give them time to relieve pressure [13]. An auditor's job is highly time-bound, client-oriented and technology intensive. Their job is often influenced by such factors such as changes in technology, client interaction, fear of obsolescence, long working hours, work overload, etc., and hence the reason why this study is carried out to establish if technostress do occur among auditors, its level, the ergonomic hazards which results from it, and how it can be reduced or avoided. An auditor's job involves the use of computers to audit around the computer, audit with the computer, or audit through the computer [14]. These tasks involve using Information Technology (IT) facilities, both hardware and software, to establish whether the computer is properly processing valid transactions, identify issues of outof-limit transactions which were processed as if they were correct, or discover where errors have been caused by overflow conditions [15]. Ahmed [16] affirmed that it is no longer possible to meet the expectations of users of financial and other business performance information without using IT and this statement was also corroborated by Doughty and O'Driscoll [17] in their argument that "a fundamental requirement for effective auditing is to provide an opinion to the executive team and the board audit committee on the adequacy of the internal control framework operating within an organisation's IT and telecommunications environment”. As such, much is often expected from auditors based on the proliferation of ICTs, since it has come to the fore, as established by Bodnar and Hopwood [18], that the benefits derivable from using computing in auditing including 1) more eligibility and consistency; 2) time saving by eliminating manual footing, cross footing, and other routine calculations; 3) accuracy in performing calculations, comparisons, and other data manipulations; 4) efficiently performing analytical review calculations; 5) easily generating and analyzing project information; 6) simplicity in modifying and storing standardized audit correspondences; 7) improving morale and productivity by reducing time spent on clerical tasks; 8) increasing cost-effectiveness by reusing and extending existing electronic audit applications to subsequent audits; and 9) increasing independence from information systems personnel are realized.

The focus of this study is thus to find out whether technostress has any impact on performance and to determine whether it has some associated hazards. This study therefore sets out to find out if technostress has any impact on performance.

\section{Statement of the Problem and Literature Review}

People are spending increasingly more and more time connected to their computers [19]. As computers and technology become ubiquitous throughout modern society, the physical and psychological effects of technology become more apparent in its users. The combination of intensive technology use and work demands has resulted in an increase 
in computer-related illnesses [20]. The negative effects of computer and technology use have been studied in many fields, and have resulted in the identification of technostress as a documented human reaction to continued interaction with technology [21]. Choo [22] defined auditor's overall job related stress as "the stress caused by his or her selfperceived inability to perform well in an ongoing auditing work environment". Auditors play a boundary-spanning role [23] and a boundary-spanner requires extensive "interactions with many people, both inside and outside the organization, with diverse needs and expectation" [24]. In order to satisfy the demands of people in their work environment, auditors could be faced with potentially stressful situations [24] [25]. As a boundary-spanner, the auditor interacts with internal staff (team members, supervisor, manager) and external parties (clients, regulators), who are subject to unforeseen problems in their work environment, which could all contribute to higher level of work related stress [26].

Auditors are exposed to a number of stressors in the workplace [27] and it has been discovered that technology is a major stressor [28]-[31]. Auditors experience stress due to high work demands of the profession, both in terms of quantity of the work [32] [33] and the need to meet tight deadlines or budgets [34] which has been enhanced by the ubiquitous nature of technological tools. Hence, this study seeks to find out the level of technostress experienced among auditors which can affect performance.

Some studies on technostress [35]-[38] found out that it could result in certain ergonomic hazards which could health, causes fatigue, infects worker relationships, cause mistake in job execution, trigger anxiety, and initiates deep psychological and physiological changes (Gardner, 2009). On the other hand, some researchers [39]-[41] concluded that it can induce employees to work more proficiently to meet set goals, as long as they are skilled in the use of technological equipment. The expansion in technology has resulted in heightened expectations for productivity, speed and efficiency, increasing pressure on individual workers to constantly operate at peak performance levels. Moreover, improvements on hardware or software often represents a technological step forward, but it also places demands on users, either to relearn tasks, troubleshoot new problems, or get comfortable with new systems, and these demands can cause a great deal of stress. Although eliminating technostress might be a herculean task, there should be ways of reducing, preventing, or coping with it. The key to dealing with technostress is to identify its causes and implement strategies to reduce it [42].

While the level of stress that workers are able to tolerate is a highly individual issue in nearly all instances, most superiors fail to recognize its power, its danger, individual vulnerability to it, and eventually, its effect (either positive or negative) on organizational performance. Socio-demographic variables (gender, age, academic qualification) have also been found to have varying effects on technostress according to [43]-[46]. Thus, identifying the level of technostress among auditors, the ergonomic hazards associated with it, its effect on performance, the likely solutions or coping strategies, and its relationship with socio-demographic variables, form the crux of this study.

Moreover, most of the studies conducted on technostress have been carried out in 
developed countries while very few have been documented in Nigeria and these have been in the education sector. The very few studies on technostress in Nigeria have been carried out in the education sector [46] [47]. Thus, lack of empirical data in the Nigerian auditing sector necessitated conducting further research to explain in more details the technostress and performance relationship.

\section{Research Objectives}

The general objective of this study is to examine the effect of technostress performance of auditing firms in Nigeria. The specific objectives of the study are to:

1) examine the level of technostress experienced among Nigerian auditors; and

2) identify the ergonomic hazards associated with Nigerian auditors' job;

3) identify the strategies adopted by workers of audit firms in Nigeria to cope with technostress.

\section{Research Hypotheses}

Ho1: There is no significant relationship between ergonomic hazard and level of technostress.

Ho2: There is no significant relationship between technostress and performance among auditors.

\section{Scope of the Study}

The study will be conducted in Lagos State, Nigeria, among the four major auditing firms referred to as the "Big Four" [48]. This is because combined 2011 revenue for the four firms rose to historic high levels of $\$ 103$ billion ( 16 trillion), up 9\% from 2010, and surpassing the previous records earlier targeted for the firms [49]. These companies also have their headquarters located in Lagos and they make use of different types of technological innovations which are subject to constant changes. The firms to be sampled are Akintola Williams Deloitte, Pricewaterhouse Coopers (PwC), KPMG, and Ernst \& Young. Aside from being the four big auditing firms, these firms are also selected because they are registered with the Institute of Chartered Accountants of Nigeria (ICAN), which is the professional body regulating the activities of accountants and auditors in Nigeria.

\section{Justification for the Study}

Information communications technologies are increasingly becoming part of everyday life. Information processing professionals see change in technology as a pre-requisite for their existence, yet the speed of this change can have profound effects [28]. However, it is felt that before such effects can be addressed with adequate and practical assistance, the existing problem must be better understood. Although considerable stress research literature exists in the context of organizational management in general, specific technostress and ergonomic studies applied to auditing and accounting fields are not abundant in the developing countries. To understand the nature of technostress 
and ergonomic hazards on firm performance, a fit must be considered between information technology (IT) facilities and the users [50]. Hence, examining the impact of technostress on public accounting firm performance is of considerable interest to both academic inquiry and practice. Such awareness would help improve performance efficiency and effectiveness, associating the actual benefits of technological facilities to performance. This research will thus be beneficial not only to auditors, but managers and directors in organizations that are constantly dependent on the use of technological facilities to accomplish office tasks.

\section{Methodology}

Simple frequency tables were used to examine the level of technostress experienced among Nigerian auditors and identify the strategies adopted by workers of audit firms in Nigeria to cope with technostress. Ergonomic hazards associated with auditors' job were examined using factor analysis, Principal Component (PC) as the method of extraction and Varimax with Kaiser Normalization as the method of rotation. The justification for using factor analysis is the high Kaiser-Meyer-Olkin Measure of Sampling Adequacy (KMO) value of 0.844 , which is well above average (0.5) and the significant Chi-Square value of Bartlett's Test of Sphericity. Analyzing the effect of technostress on the performance of auditors, Likelihood Ratio Tests were carried out at a 0.05 level of significance.

\section{Results}

A total of 850 questionnaires were administered to members of staff in the various auditing departments covered and 825 questionnaires were retrieved back, giving a response rate of $94.93 \%$. This was achieved by producing extra copies of the questionnaire to make up for copies not returned.

\subsection{Socio-Demographic Data of Respondents}

From the analysis of the data obtained on the gender of the respondents in Table 1, it was discovered that there was much difference in the distribution of the sex of auditors who work in the selected auditing firms. From Table 1, 56.2\% of these individuals were male, while $42.8 \%$ were female. This shows that the work of auditors was more dominated by the male gender. This can be adduced to the fact that female auditors experience significantly high job burnout than their male counterparts as reported by Larson [51] in a study carried out to analyse gender differences among auditors. Moreover, male auditors could find the auditing job more satisfying than their female counterparts as supported by Takhtaei and Dezfully [52] in their study of the impact of gender upon the perception of auditors' job.

Majority of the respondents fall within the age brackets of $22-27$ years (41.5\%) and 28 - 33 years (40.4\%). A few of the respondents (12.8\%) are within the age bracket of 34 39 years while only 30 respondents (3.6\%) out of a total of 825 , are above 40 years of age. This shows that a vibrant and younger age continuum dominate a larger percentage of the workforce. 
Table 1. Socio-demographic data of respondents in auditing firms.

\begin{tabular}{cccc}
\hline Socio-Demographic Data & No. of Respondents (Frequency) & Percentage (\%) \\
\hline No response & 8 & 1.0 \\
Male & 464 & 56.2 \\
Female & 353 & 42.8 \\
Total & 825 & 100.0 \\
No response & 14 & 1.7 \\
22 - 27 years & 342 & 41.5 \\
28 - 33 years & 333 & 40.4 \\
Age & - 39 years & 106 & 12.8 \\
& Above 40 years & 30 & 3.6 \\
Total & 825 & 100.0 \\
& No response & 14 & 1.7 \\
B.Sc. & 303 & 36.7 \\
OND & 217 & 26.3 \\
HND & 202 & 24.5 \\
Masters & 89 & 10.8 \\
& Total & 825 & 100.0 \\
\hline
\end{tabular}

Source: Field Survey, 2014.

Also from Table 1, the respondents in all the selected firms have varied qualifications. Respondents who have B.Sc. degrees are however in the majority (36.7\%). This is followed by Ordinary National Degree (OND) holders (26.3\%), Higher National Degree (HND) holders (24.5\%) and Master's Degree holders (10.8\%).

\subsection{Technostress Level among Auditors}

\subsubsection{Average Technostress Level}

In order to measure the level of technostress in this study, fourteen (14) variables were itemized on a Likert Scale. Respondents ticked their level of agreement with each specific statement on the five-point Likert Scale (from "very low technostress level" at one, to "very high technostress level" at five). The total number of retrieved questionnaires is 825 . Out of the 825 responses to the measure of technostress by the respondents, only 813 responses were valid and were used to determine the mean value. Responses less than the 14 required items were grouped as invalid. Pulling the variables together, the scale was grouped into "very low technostress level" and "very high technostress level" and the mean value as calculated using SPSS statistical package was given as 52.20. The minimum value that was obtained from the analysis of the selection of "very low technostress level" was 15 while the maximum value that was obtained from the selection of "very high technostress level" was 70. Thus, variables which fell within the range of 15 and 52.20 constituted the "low technostress level" while variables which fell within the 
range of 52.20 and 70.0 made up the "high technostress level". This is shown on Table 2.

\subsubsection{Individual Technostress Level}

Given a mean value of 52.20, the level of technostress from 15 to the mean value was tagged "low level of technostress" while that from the mean value to 70 was tagged "high level of technostress" (Table 2). Similarly, Table 3 shows that some individual auditors recorded high technostress levels as a result of slow computer speed (89.5\%), slow internet connectivity (88.1\%), network failure when it is needed for work (86.6\%), and intrusion of ICT on private life (83.8\%). However, it is observed, from Table 4, that 418 auditors (51.4\%) have a low level of technostress while 395 auditors (48.6\%) have a high level of technostress. Since the auditors with low level of technostress slightly outweigh those with high level, it can be implied that the possibility and occurrences of technostress among auditors cannot be completely ruled out.

Table 2. Average value for technostress level.

\begin{tabular}{cccc}
\hline Number of Valid Respondents & Mean & Minimum value & Maximum value \\
\hline 813 & 52.20 & 15 & 70 \\
\hline
\end{tabular}

Source: Field Survey, 2014.

Table 3. Individual level of technostress among auditors.

\begin{tabular}{|c|c|c|c|c|c|c|c|c|c|c|}
\hline \multirow{2}{*}{$\begin{array}{c}\text { Technostress level in terms of this } \\
\text { item }\end{array}$} & \multicolumn{2}{|c|}{$\begin{array}{c}\text { Very low } \\
\text { technostress }\end{array}$} & \multicolumn{2}{|c|}{$\begin{array}{l}\text { Low } \\
\text { technostress }\end{array}$} & \multicolumn{2}{|c|}{$\begin{array}{c}\text { Medium } \\
\text { technostress }\end{array}$} & \multicolumn{2}{|c|}{$\begin{array}{c}\text { High } \\
\text { technostress }\end{array}$} & \multicolumn{2}{|c|}{$\begin{array}{l}\text { Very high } \\
\text { technostress }\end{array}$} \\
\hline & $\mathrm{f}$ & $\%$ & $\mathrm{f}$ & $\%$ & $\mathrm{f}$ & $\%$ & $\mathrm{f}$ & $\%$ & $\mathrm{f}$ & $\%$ \\
\hline Slow computer speed & 2 & 0.2 & 13 & 1.6 & 70 & 8.6 & 312 & 38.2 & 419 & 51.3 \\
\hline Slow internet connection & 4 & 0.5 & 12 & 1.5 & 81 & 9.9 & 355 & 43.6 & 363 & 44.5 \\
\hline $\begin{array}{l}\text { Network failure when needed } \\
\text { for work }\end{array}$ & 9 & 1.1 & 17 & 2.1 & 82 & 10.2 & 334 & 41.5 & 363 & 45.1 \\
\hline Intrusion of ICT on private life & 7 & 0.9 & 24 & 3.0 & 98 & 12.3 & 333 & 41.8 & 335 & 42.0 \\
\hline $\begin{array}{l}\text { Spending much time in front of } \\
\text { the computer }\end{array}$ & 7 & 0.9 & 13 & 1.6 & 128 & 15.9 & 303 & 37.6 & 354 & 44.0 \\
\hline $\begin{array}{l}\text { Learning to use a new software or } \\
\text { technology for the first time }\end{array}$ & 17 & 2.1 & 46 & 5.7 & 161 & 20.0 & 316 & 39.3 & 264 & 32.8 \\
\hline $\begin{array}{l}\text { Loss of data as a result of virus } \\
\text { invasion on computer }\end{array}$ & 25 & 3.1 & 90 & 11.3 & 216 & 27.1 & 261 & 32.7 & 205 & 25.7 \\
\hline $\begin{array}{l}\text { Loss of data as a result of using } \\
\text { new technology }\end{array}$ & 32 & 4.0 & 105 & 13.2 & 235 & 29.6 & 251 & 31.6 & 171 & 21.5 \\
\hline $\begin{array}{l}\text { Having to cram different passwords } \\
\text { for different websites or programs }\end{array}$ & 29 & 3.6 & 134 & 16.8 & 251 & 31.5 & 240 & 30.1 & 144 & 18.0 \\
\hline $\begin{array}{c}\text { Having more competent people } \\
\text { who use ICTs around you }\end{array}$ & 34 & 4.3 & 119 & 14.9 & 221 & 27.7 & 258 & 32.3 & 166 & 20.8 \\
\hline $\begin{array}{l}\text { Information overload provided } \\
\text { by internet }\end{array}$ & 29 & 3.6 & 110 & 13.8 & 268 & 33.7 & 238 & 29.9 & 151 & 19.0 \\
\hline Cost of ICT products & 44 & 5.5 & 184 & 23.1 & 227 & 28.6 & 212 & 26.7 & 128 & 16.1 \\
\hline $\begin{array}{l}\text { Having to transfer data from } \\
\text { one system to another }\end{array}$ & 48 & 6.0 & 152 & 19.0 & 249 & 31.2 & 217 & 27.2 & 133 & 16.6 \\
\hline $\begin{array}{l}\text { Pressure from the organization } \\
\text { or society to learn new ICTs }\end{array}$ & 42 & 5.2 & 108 & 13.5 & 233 & 29.1 & 262 & 32.8 & 155 & 19.4 \\
\hline
\end{tabular}

Source: Field Survey, 2014. 


\subsection{Ergonomic Hazards Associated with Auditors' Job}

Several hazards have been found to be associated with an auditor's job. As depicted in Table 5, top on the list of the hazards is back pain, which has a percentage of $71.52 \%$. This is followed by headache, which was reported by $69.82 \%$ of the respondents. Low on the list is visual fatigue (41.33\%), inadequate sleep (30.91\%), wrist pain (54.67\%), numbness in finger $(36.12 \%)$, poor posture $(30.55 \%)$, migraine $(46.55 \%)$, and depression $(14.18 \%)$. These hazards were claimed to be caused by poor lighting in office areas, poor screen resolution, poor screen positioning, inability to adjust monitor (for respondents who use a desktop), and inability to adjust chair height in the most appropriate angle. Others are difficulty to copy materials from the screen, lack of ability to take frequent breaks when tired, inability to use mouse pad while working on the computer, provision of chair without armrests, inappropriate size and shape of chair, and display screen being too close to sitting position.

Ergonomic hazards associated with auditors' job were examined using factor analysis, Principal Component (PC) as the method of extraction and Varimax with Kaiser Normalization as the method of rotation (Table 6). The justification for using factor analysis is the high KMO value of 0.844 which is well above average (0.5) and the significant Chi-Square value of Bartlett's Test of Sphericity.

The rotated component matrix showing the factor loadings of the factors are shown below (Table 7).

Table 4. Overall level of technostress among auditors.

\begin{tabular}{ccc}
\hline Level of Technostress & Frequency & Percentage \\
\hline Low & 418 & 51.4 \\
High & 395 & 48.6 \\
Total & $\mathbf{8 1 3}$ & 100 \\
\hline
\end{tabular}

Source: Field Survey, 2014

Table 5. Ergonomic hazards associated with auditors' job.

\begin{tabular}{ccc}
\hline Ergonomic Hazard & Frequency* & Percentage (\%) \\
\hline Headache & 576 & 69.82 \\
Neck pain & 573 & 69.45 \\
Migraine & 384 & 46.55 \\
Back pain & 590 & 71.52 \\
Visual fatigue & 341 & 41.33 \\
Poor posture & 252 & 30.55 \\
Numbness in fingers & 298 & 36.12 \\
Wrist pain & 451 & 54.67 \\
Inadequate sleep & 255 & 30.91 \\
Depression & 117 & 14.18
\end{tabular}

${ }^{*}$ Multiple responses were considered in computing the frequency. Source: Field Survey, 2014. 
Table 6. KMO and Bartlett's test.

\begin{tabular}{lcc}
\hline \multicolumn{2}{c}{ Kaiser-Meyer-Olkin Measure of Sampling Adequacy. } & 0.844 \\
\hline & Approx. Chi-Square & 2546.220 \\
Bartlett's Test of Sphericity & df & 45 \\
& Sig. & 0.000 \\
\hline
\end{tabular}

Source: Field Survey, 2014.

Table 7. Rotated component matrix with groupings.

\begin{tabular}{|c|c|c|c|c|c|}
\hline \multirow{3}{*}{ Items } & \multicolumn{3}{|c|}{ Rotated Component Matrix } & \multirow{3}{*}{$\begin{array}{l}\text { Group/Factor } \\
\text { Belonging }\end{array}$} & \multirow{3}{*}{$\begin{array}{l}\text { Items having factor } \\
\text { loadings above } 0.6\end{array}$} \\
\hline & & \multicolumn{2}{|c|}{ Component } & & \\
\hline & & 1 & 2 & & \\
\hline 1 & Headache & 0.055 & 0.710 & 2 & Yes \\
\hline 2 & Neck pain & 0.062 & 0.814 & 2 & Yes \\
\hline 3 & Migraine & 0.263 & 0.771 & 2 & Yes \\
\hline 4 & Back pain & 0.074 & 0.769 & 2 & Yes \\
\hline 5 & Visual fatigue & 0.717 & 0.096 & 1 & Yes \\
\hline 6 & Poor posture & 0.767 & -0.012 & 1 & Yes \\
\hline 7 & Numbness in fingers & 0.722 & 0.071 & 1 & Yes \\
\hline 8 & Wrist pain & 0.501 & 0.475 & 1 & No \\
\hline 9 & Inadequate sleep & 0.626 & 0.390 & 1 & Yes \\
\hline 10 & Depression & 0.698 & 0.133 & 1 & Yes \\
\hline
\end{tabular}

Extraction Method: Principal Component Analysis. Rotation Method: Varimax with Kaiser Normalization. Note: $\mathrm{p}<$ 0.05 indicates significant difference. Source: Field Survey, 2014.

The factor loadings of the items are presented in Table 7. There was consistency in the observed pattern as indicated by an average Kaiser-Meyer-Olkin Measure of Sampling Adequacy of 0.844. For example, all of the items loaded to at least one of the two identified components. Hence, there was no need for re-running the analysis. However, an item was removed since its factor loading fell below 0.6. (i.e. Item 8-wrist pain). This reduced the total number of items (i.e. ergonomic hazards associated with auditors' job) from 10 to 9 significant hazards. The use of 0.6 as the cut-off for factor loading is justified by the averagely low percentage of total variance explained (i.e. $55.961 \%)$. The factor analysis does not explain beyond this percentage, hence the need to increase accuracy from the average cut-off of 0.5 to 0.6 (Table 8).

Each of the items remaining was grouped under the two identified components or groups of factors which are:

Group 1 (pain-centric ergonometric hazards): members of this group are items 1 to 4 (headache, neck pain, migraine, and back pain).

Group 2 (non-pain based ergonometric hazards): members of this group are items 5 to 7, 9 and 10 (visual fatigue, poor posture, numbness in fingers, inadequate sleep, and 
depression). The two identified components or groups of factors can be pictorially depicted by the scree plot (Figure 1).

\subsection{Relationships between Ergonomic Hazard Intensity and Level of Technostress Using Logistic Regression}

The intensities of ergonomic hazards associated with auditors' job were related to the level of technostress using discriminate analysis called logistic regression. Binary logistic regression was chosen because the dependent variable (level of technostress) has two levels of measurement (low and high) while the independent variables (ergonomic hazards) were varied from non-existent to high intensities. The overall impact of ergonomic

Table 8. Total variance explained before item removal.

\begin{tabular}{|c|c|c|c|c|c|c|c|c|c|}
\hline \multirow{2}{*}{ Component } & \multicolumn{3}{|c|}{ Initial Eigenvalues } & \multicolumn{3}{|c|}{ Extraction Sums of Squared Loadings } & \multicolumn{3}{|c|}{ Rotation Sums of Squared Loadings } \\
\hline & Total & $\%$ of Variance & Cumulative \% & Total & $\%$ of Variance & Cumulative \% & Total & $\%$ of Variance & Cumulative $\%$ \\
\hline 1 & 3.834 & 38.341 & 38.341 & 3.834 & 38.341 & 38.341 & 2.835 & 28.345 & 28.345 \\
\hline 2 & 1.762 & 17.620 & 55.961 & 1.762 & 17.620 & 55.961 & 2.762 & 27.616 & 55.961 \\
\hline 3 & 0.802 & 8.024 & 63.985 & & & & & & \\
\hline 4 & 0.742 & 7.418 & 71.404 & & & & & & \\
\hline 5 & 0.574 & 5.739 & 77.142 & & & & & & \\
\hline 6 & 0.536 & 5.364 & 82.507 & & & & & & \\
\hline 7 & 0.491 & 4.915 & 87.421 & & & & & & \\
\hline 8 & 0.452 & 4.519 & 91.941 & & & & & & \\
\hline 9 & 0.447 & 4.472 & 96.413 & & & & & & \\
\hline 10 & 0.359 & 3.587 & 100.000 & & & & & & \\
\hline
\end{tabular}

Extraction Method: Principal Component Analysis. Source: Field Survey, 2014.

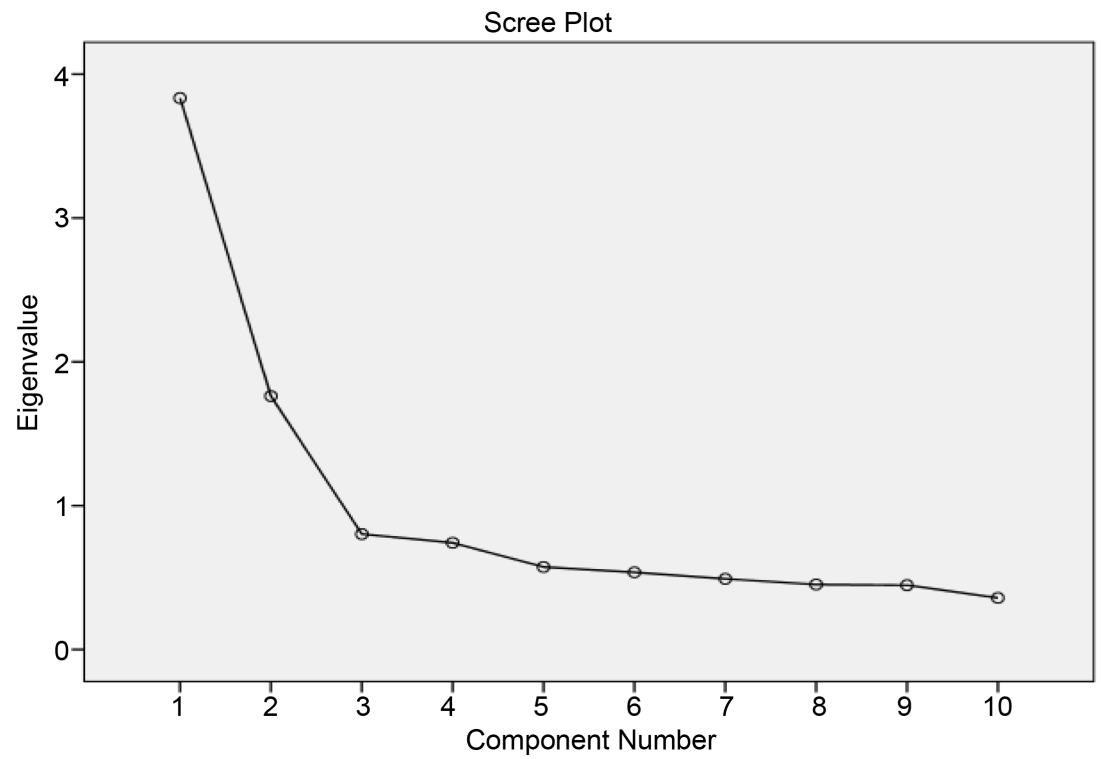

Figure 1. Scree plot indicating justification for two component selections. 
hazards on the level of technostress was first captured before examining the relationship between the individual ergonomic hazards and the level of technostress. To test whether there is no significant relationship between technostress and ergonomic hazards among auditors, $\log$ likelihood test was used. The result is presented in Table 9.

Hypothesis testing shows a likelihood ratio value of 45.904 while the " $p$ " value is 0.0 , reported as $\chi^{2}(10)=45.904, \mathrm{p}<0.05$. It was also observed that the $\mathrm{p}$-value is less than 0.05 used as significance level. Since the p-value is less than the significance level of 0.05 , there is a significant relationship between technostress and ergonomic hazards among auditors. Therefore, the null hypothesis is rejected. The interpretation is that there appears to be substantial contribution of ergonomic hazards to the technostress levels faced by auditors. However, irrespective of the joint effect of ergonomic hazards on the level of technostress, the individual effect may reveal how each ergonomic hazard is related to the level of technostress. The result is captured in the succeeding Tables 10-13.

\section{Key}

Dependent variable coding

\begin{tabular}{cc}
\hline Parameter coding & Overall technostress levels \\
\hline 0 & Low \\
1 & High \\
\hline
\end{tabular}

Table 9. Relationship between ergonomic hazard intensity and level of technostress.

\begin{tabular}{cccc}
\hline Log likelihood ratio chi-square & df & $\mathrm{p}$ \\
\hline 45.904 & 10 & 0.00 \\
\hline
\end{tabular}

Source: Field Survey, 2014.

Table 10. Individual effect of ergonomic hazard to the level of technostress variables in the equation.

\begin{tabular}{|c|c|c|c|c|c|c|c|c|c|}
\hline \multirow{2}{*}{ Ergonomic hazards } & \multirow{2}{*}{ B } & \multirow{2}{*}{ S.E. } & \multirow{2}{*}{\multicolumn{2}{|c|}{ Wald df }} & \multirow{2}{*}{ Sig. } & \multirow{2}{*}{$\operatorname{Exp}(B)$} & \multicolumn{2}{|c|}{ 95\% C.I. for $\operatorname{EXP}(B)$} & \multirow{2}{*}{ Probability } \\
\hline & & & & & & & Lower & Upper & \\
\hline Headache & 0.232 & 0.093 & 6.249 & 1 & 0.012 & 1.261 & 1.051 & 1.513 & 0.56 \\
\hline Neck pain & -0.300 & 0.109 & 7.524 & 1 & 0.006 & 0.741 & 0.598 & 0.918 & 0.43 \\
\hline Visual fatigue & -0.103 & 0.095 & 1.185 & 1 & 0.276 & 0.902 & 0.749 & 1.086 & 0.47 \\
\hline Poor posture & 0.257 & 0.112 & 5.315 & 1 & 0.021 & 1.294 & 1.039 & 1.610 & 0.56 \\
\hline Migraine & -0.208 & 0.090 & 5.312 & 1 & 0.021 & 0.812 & 0.680 & 0.969 & 0.45 \\
\hline Numbness in fingers & 0.236 & 0.099 & 5.703 & 1 & 0.017 & 1.266 & 1.043 & 1.536 & 0.56 \\
\hline Wrist pain & 0.068 & 0.089 & 0.585 & 1 & 0.445 & 1.070 & 0.899 & 1.273 & 0.52 \\
\hline Back pain & -0.072 & 0.089 & 0.659 & 1 & 0.417 & 0.931 & 0.782 & 1.107 & 0.48 \\
\hline Depression & -0.225 & 0.105 & 4.653 & 1 & 0.031 & 0.798 & 0.650 & 0.980 & 0.44 \\
\hline Inadequate sleep & -0.002 & 0.098 & 0.000 & 1 & 0.986 & 0.998 & 0.824 & 1.210 & 0.50 \\
\hline
\end{tabular}

Source: Field Survey, 2014. 
Table 11. Interpretation.

Headache There is no significant relationship between the headache ergonomic hazard intensities and levels of techno stress. Specifically, there is a 0.56 (56\%) probability that auditors who experience headache ergonomic hazards will have increased technostress levels.

Neck pain There is a significant relationship between the neck pain ergonomic hazard intensity and levels of techno stress. Specifically, there is a $0.43(43 \%)$ probability that auditors who experience neck pain ergonomic hazards will have increased technostress levels.

There is no significant relationship between the visual fatigue ergonomic hazard intensity and levels of techno stress. Specifically,

Visual fatigue there is a $0.47(47 \%)$ probability that auditors who experience visual fatigue ergonomic hazards will have increased technostress levels.

There is no significant relationship between the poor posture ergonomic hazard intensity and levels of techno stress. Specifically,

Poor posture there is a $0.56(56 \%)$ probability that auditors who experience poor posture ergonomic hazards will have increased technostress levels.

Migraine There is no significant relationship between the migraine ergonomic hazard intensity and levels of techno stress. Specifically, there is a $0.45(45 \%)$ probability that auditors who experience migraine ergonomic hazards will have increased technostress levels.

Numbness in There is no significant relationship between the numbness in fingers ergonomic hazard intensity and levels of techno stress. fingers Specifically, there is a $0.56(56 \%)$ probability that auditors who experience numbness in fingers ergonomic hazards will have increased technostress levels.

Wrist pain There is no significant relationship between the wrist pain ergonomic hazard intensity and levels of techno stress. Specifically, there is a $0.52(52 \%)$ probability that auditors who experience wrist pain ergonomic hazards will have increased technostress levels.

Back pain There is no significant relationship between the back pain ergonomic hazard intensity and levels of techno stress. Specifically, there is a $0.48(48 \%)$ probability that auditors who experience back pain ergonomic hazards will have increased technostress levels.

Depression There is no significant relationship between the depression ergonomic hazard intensity and levels of techno stress. Specifically, there is a $0.44(44 \%)$ probability that auditors who experience depression ergonomic hazards will have increased technostress levels.

Inadequate There is no significant relationship between the inadequate sleep ergonomic hazard intensity and levels of techno stress. sleep Specifically, there is a $0.50(50 \%)$ probability that auditors who experience inadequate sleep ergonomic hazards will have increased technostress levels.

Note: the underlying assumption behind the probability computation is that each independent variable influences the dependent variable separately.

\section{Significant Relationships between Ergonomic Hazard Intensity and Level of Technostress}

Table 12. Percentage distribution of respondents by significant ergonomic hazards relating to level of technostress.

\begin{tabular}{|c|c|c|c|c|c|c|c|c|c|c|}
\hline & & \multicolumn{6}{|c|}{ Overall Level of Technostress among Auditors } & \multirow{3}{*}{ Wald } & \multirow{3}{*}{$\mathrm{df}$} & \multirow{3}{*}{ Sig. } \\
\hline & & \multicolumn{2}{|c|}{ Low } & \multicolumn{2}{|c|}{ High } & \multicolumn{2}{|c|}{ Total } & & & \\
\hline & & $\mathrm{f}$ & $\%$ & $\mathrm{f}$ & $\%$ & $\mathrm{f}$ & $\%$ & & & \\
\hline \multirow{5}{*}{ Neck pain } & Low & 36 & 9.0 & 70 & 18.3 & 106 & 13.6 & \multirow{5}{*}{7.524} & \multirow{5}{*}{1} & \multirow{5}{*}{0.006} \\
\hline & Moderate & 83 & 20.9 & 79 & 20.6 & 162 & 20.7 & & & \\
\hline & High & 259 & 65.1 & 195 & 50.9 & 454 & 58.1 & & & \\
\hline & Non-existent & 20 & 5.0 & 39 & 10.2 & 59 & 7.6 & & & \\
\hline & Total & 398 & 100.0 & 383 & 100.0 & 781 & 100.0 & & & \\
\hline
\end{tabular}

Source: Field Survey, 2014.

\section{Binary Logistic Model:}

Technostress $(1)=0.232 *$ Headache $+-0.300 *$ Neck pain $+-0.103 *$ Visual fatigue + $0.257 *$ Poor posture $(1)+-0.208 *$ Migraine $+0.236 *$ Numbness in fingers (3) +0.068

* Wrist pain $+-0.072 *$ Back pain $+-0.225 *$ Depression $+-0.002 *$ Inadequate sleep. 
Non-Significant Relationships between Ergonomic Hazard Intensity and Level of Technostress

Table 13. Percentage distribution of respondents by non-significant ergonomic hazards relating to level of technostress.

\begin{tabular}{|c|c|c|c|c|c|c|c|c|}
\hline & & \multicolumn{6}{|c|}{ Overall Level of Technostress among Auditors } & \multirow[t]{3}{*}{ Wald df Sig. } \\
\hline & & \multicolumn{2}{|c|}{ Low } & \multicolumn{2}{|c|}{ High } & \multicolumn{2}{|c|}{ Total } & \\
\hline & & $\mathrm{f}$ & $\%$ & $\mathrm{f}$ & $\%$ & $\mathrm{f}$ & $\%$ & \\
\hline \multirow{4}{*}{ Visual fatique } & Non existent & 32 & 8.1 & 46 & 12.1 & 78 & 10.1 & \multirow[t]{4}{*}{1.18510 .276} \\
\hline & Low & 114 & 28.9 & 116 & 30.4 & 230 & 29.6 & \\
\hline & Moderate & 134 & 33.9 & 126 & 33.1 & 260 & 33.5 & \\
\hline & High & 115 & 29.1 & 93 & 24.4 & 208 & 26.8 & \\
\hline \multirow{4}{*}{ Wrist pain } & Non-existent & 39 & 9.8 & 40 & 10.5 & 79 & 10.2 & \multirow[t]{4}{*}{$0.585 \quad 1 \quad 0.445$} \\
\hline & Low & 56 & 14.1 & 78 & 20.5 & 134 & 17.2 & \\
\hline & Moderate & 101 & 25.5 & 90 & 23.6 & 191 & 24.6 & \\
\hline & High & 200 & 50.5 & 173 & 45.4 & 373 & 48.0 & \\
\hline \multirow{4}{*}{ Back pain } & Non-existent & 34 & 8.6 & 48 & 12.6 & 82 & 10.5 & \multirow[t]{4}{*}{$0.659 \quad 10.417$} \\
\hline & Low & 43 & 10.8 & 79 & 20.7 & 122 & 15.7 & \\
\hline & Moderate & 57 & 14.4 & 54 & 14.1 & 111 & 14.2 & \\
\hline & High & 263 & 66.2 & 201 & 52.6 & 464 & 59.6 & \\
\hline \multirow{4}{*}{ Inadequate sleep } & Non-existent & 114 & 29.3 & 155 & 40.9 & 269 & 35.0 & \multirow[t]{4}{*}{$0.000 \quad 10.986$} \\
\hline & Low & 167 & 42.9 & 143 & 37.7 & 310 & 40.4 & \\
\hline & Moderate & 70 & 18.0 & 42 & 11.1 & 112 & 14.6 & \\
\hline & High & 38 & 9.8 & 39 & 10.3 & 77 & 10.0 & \\
\hline \multirow{5}{*}{ Headache } & Low & 39 & 9.8 & 57 & 14.9 & 96 & 12.3 & \multirow{5}{*}{$6.249 \quad 10.012$} \\
\hline & Moderate & 102 & 25.6 & 67 & 17.5 & 169 & 21.6 & \\
\hline & High & 236 & 59.1 & 228 & 59.5 & 464 & 59.3 & \\
\hline & Non-existent & 22 & 5.5 & 31 & 8.1 & 53 & 6.8 & \\
\hline & Total & 399 & 100.0 & 383 & 100.0 & 782 & 100.0 & \\
\hline \multirow{4}{*}{ Poor posture } & Non existent & 41 & 10.5 & 46 & 12.0 & 87 & 11.3 & \multirow{4}{*}{$\begin{array}{llll}5.315 & 1 & 0.021\end{array}$} \\
\hline & Low & 148 & 37.9 & 138 & 36.1 & 286 & 37.0 & \\
\hline & Moderate & 133 & 34.0 & 137 & 35.9 & 270 & 34.9 & \\
\hline & High & 69 & 17.6 & 61 & 16.0 & 130 & 16.8 & \\
\hline \multirow{4}{*}{ Migraine } & Non-existent & 65 & 16.5 & 117 & 30.7 & 182 & 23.5 & \multirow{4}{*}{$\begin{array}{lll}5.312 & 1 & 0.021\end{array}$} \\
\hline & Low & 91 & 23.1 & 85 & 22.3 & 176 & 22.7 & \\
\hline & Moderate & 144 & 36.5 & 107 & 28.1 & 251 & 32.4 & \\
\hline & High & 94 & 23.9 & 72 & 18.9 & 166 & 21.4 & \\
\hline \multirow{4}{*}{ Numbness in fingers } & Non existent & 51 & 13.0 & 55 & 14.4 & 106 & 13.7 & \multirow{4}{*}{$\begin{array}{lll}5.703 & 1 & 0.017\end{array}$} \\
\hline & Low & 158 & 40.4 & 141 & 37.0 & 299 & 38.7 & \\
\hline & Moderate & 127 & 32.5 & 111 & 29.1 & 238 & 30.8 & \\
\hline & High & 55 & 14.1 & 74 & 19.4 & 129 & 16.7 & \\
\hline \multirow{4}{*}{ Depression } & Non-existent & 162 & 41.3 & 196 & 51.4 & 358 & 46.3 & \multirow{4}{*}{$\begin{array}{lll}4.653 & 1 & .031\end{array}$} \\
\hline & Low & 144 & 36.7 & 135 & 35.4 & 279 & 36.1 & \\
\hline & Moderate & 46 & 11.7 & 27 & 7.1 & 73 & 9.4 & \\
\hline & High & 40 & 10.2 & 23 & 6.0 & 63 & 8.2 & \\
\hline
\end{tabular}

Source: Field Survey, 2014. 


$$
P(\operatorname{technostress}(1))=\frac{e^{\text {technostress }(1)}}{1+e^{\text {technostress }(1)}} .
$$

\subsection{Strategies Adopted by Auditors to Cope with Technostress}

Auditors embrace several strategies in order to cope with technostress. From the respondents' reaction to technostress in their work environment, some basic common themes emerged, all related to management practices.

Top among these strategies as depicted in Table 14, is the provision of ICT which fit the needs of auditors work task, which was supported by $80.61 \%$ of the respondents. Some of the other coping strategies as suggested by the auditors include provision of adequate and easy-to-use software by $77.21 \%$ of the respondents, provision of ICTs to fulfill the requirement of auditors work task by $76.61 \%$ of the respondents, and ensuring that breaks are observed within office hours by $75.39 \%$ of the respondents.

\subsection{Effect of Technostress on Performance of Auditors}

To measure performance in this study, twenty (20) variables were itemized on a Likert Scale. Pulling all the individual variables that made up performance together and using the mean value (56.9077), the performance level was grouped into "unsatisfactory performance", "satisfactory performance" and "outstanding performance". The minimum value that was obtained from the selection of "unsatisfactory performance" was 20 while the maximum value that was obtained from the selection of "outstanding performance" was 98. Variables which fell within the range of 20 and 56.9 constituted the "unsatisfactory performance", variables which fell within the range of 57 and 77.4 made

Table 14. Percentage distribution of strategies to address technostress.

\begin{tabular}{ccc}
\hline Strategies to address technostress & No. of respondents (frequency) & $\%$ \\
\hline Provision of ICT which fit the needs of my work task & 665 & 80.61 \\
Provision of adequate and easy to use software & 637 & 77.21 \\
Provision of ICTs to fulfill the requirement of my work task & 632 & 76.61 \\
Ensuring that breaks are observed within office hours & 622 & 75.39 \\
A march between the ICTs I use and my work demands & 614 & 74.42 \\
Provision of adequate office furniture & 558 & 67.64 \\
Provision of up to date network infrastructure & 558 & 67.64 \\
Easy accessibility of end user help desk & 536 & 64.97 \\
Provision of adequate training for employees before the & 509 & 61.70 \\
Provision of end user help desk that is responsive to end user \\
request
\end{tabular}

Source: Field Survey, 2014. 
up the "satisfactory performance", while variables which fell within the range of 77.5 and 98 constituted the "outstanding performance".

Analysing the effect of technostress on the performance of auditors, Likelihood Ratio Tests were carried out at a 0.05 level of significance. This tests the null hypothesis that says there is no significant relationship between technostress and performance among auditors. From Tables 15-17, the result of the test shows that there is significant relationship between technostress and performance of auditors $\left(\chi^{2}=332.377 ; \mathrm{p}=0.00\right)$. The chi-square statistic is the difference in -2 log-likelihoods between the models evaluated. The null hypothesis is that all parameters of the effect from the evaluated models are 0.

Table 15. Likelihood ratio tests.

\begin{tabular}{ccccc}
\hline \multirow{2}{*}{ Effect } & \multicolumn{2}{c}{ Model Fitting Criteria } & \multicolumn{2}{c}{ Likelihood Ratio Tests } \\
\cline { 2 - 5 } & -2 Log Likelihood of Reduced Model & Chi-Square & df & Sig. \\
\hline Overall_Level_Technostress & 355.211 & 332.377 & 4 & 0.000 \\
\hline
\end{tabular}

Table 16. Parameter estimates.

\begin{tabular}{|c|c|c|c|c|c|c|c|c|}
\hline \multirow{2}{*}{\multicolumn{2}{|c|}{ Performance of Auditors ${ }^{\star}$}} & \multirow{2}{*}{ B } & \multirow{2}{*}{ Std. Error } & \multirow{2}{*}{ Wald df Sig. } & \multicolumn{3}{|c|}{ 95\% Confidence Interval for $\operatorname{Exp}(B)$} & \multirow{2}{*}{ Probability } \\
\hline & & & & & Lxp(D) & Lower Bound & Upper Bound & \\
\hline \multirow{2}{*}{ Satisfactory performance } & {$[$ technostress $=0]$} & 1.051 & 0.131 & 64.67210 .000 & 2.861 & 2.214 & 3.696 & 0.74 \\
\hline & [technostress $=1]$ & 1.445 & 0.146 & 97.98510 .000 & 4.241 & 3.186 & 5.646 & 0.81 \\
\hline \multirow{2}{*}{ Outstanding performance } & {$[$ technostress $=0]$} & -0.399 & 0.178 & $5.054 \quad 10.025$ & 0.671 & 0.474 & 0.950 & 0.40 \\
\hline & [technostress $=1]$ & -0.169 & 0.194 & $0.755 \quad 10.385$ & 0.845 & 0.578 & 1.236 & 0.46 \\
\hline
\end{tabular}

${ }^{*}$ The reference category is: Unsatisfactory performance. Before model fitting, the initial assumption is that the auditors possess unsatisfactory performance level. Source: Field Survey, 2014.

Table 17. Interpretation.

\footnotetext{
Low There is a significant relationship between low technostress levels and satisfactory performance among auditors. Specifically, Low there is a $74 \%$ probability that auditors who experience low technostress levels will have satisfactory performance or there is a
technostress levels $26 \%$ probability that auditors who experience low technostress levels will have unsatisfactory performance. technostress levels there is a $81 \%$ probability that auditors who experience high technostress levels will have satisfactory performance (irrespective of the high technostress) provided there is equally adequate coping strategies.

High There is a significant relationship between high technostress levels and satisfactory performance among auditors. Specifically,

There is a significant relationship between low technostress levels and outstanding satisfactory performance among auditors.

Low Particularly, there is a $40 \%$ probability that auditors who experience low technostress levels will have outstanding performance. Low It is expected that the lower the stress the better the performance, however, a less than average probability suggests that other
technostress levels
factors are necessary for this to be true. There more variables involved in assessing the performance of auditors other than technostress.
}

There is a non-significant relationship between high technostress levels and outstanding satisfactory performance among

High auditors. While technostress levels may not be the only determinant in assessing the performance of auditors, it is a major technostress levelsfactor to be considered since outstanding satisfactory performance among auditors cannot be achieved or related to high technostress levels.

Note: the underlying assumption behind the probability computation is that each independent variable influences the dependent variable separately. Source: Field Survey, 2014. 
Key

Independent variable coding

\begin{tabular}{cc}
\hline Parameter coding & Overall technostress levels \\
\hline 0 & Low \\
1 & High \\
\hline
\end{tabular}

Dependent variable coding

\begin{tabular}{cc}
\hline Parameter coding & Performance \\
\hline 0 & Unsatisfactory performance \\
1 & Satisfactory performance \\
2 & Outstanding performance \\
\hline
\end{tabular}

Multinomial logistic regression model:

performance $(1)=1.051 *$ technostress $(0)+1.445^{\star}$ technostress $(1)$

performance $(2)=-0.399 *$ technostress $(0)+-0.169 *$ technostress $(1)$

$$
\begin{gathered}
P(\text { performance }(1))=\frac{e^{\text {performance }(1)}}{1+e^{\text {performance }(1)}} \\
P(\text { performance }(2))=\frac{e^{\text {performance }(2)}}{1+e^{\text {performance }(2)}} .
\end{gathered}
$$

\section{Discussion of Findings}

This study explored the relationship between technostress, ergonomic hazards and performance within the big four auditing firms in Nigeria, which are KPMG, Akintola Williams Delloite, PwC, and E \& Y. Overall, the results indicated that technostress is on a moderate level (the mean value was calculated using SPSS statistical package as 52.20) in the organisations considered, although, some auditors experienced it on the high side on an individual level (some individual auditors recorded high technostress levels as a result of slow computer speed (89.5\%), slow internet connectivity (88.1\%), network failure when it is needed for work (86.6\%), and intrusion of ICT on private life (83.8\%).

Contrary to the original hypothesis that there is no significant relationship between technostress and ergonomic hazards, it was shown, using logistic regression, that technostress triggered only the neck pain hazard, which was supported by the outcome of findings in previous literatures [37], [47], and [53]. An interesting finding of this study is that technostress was found not to have any correlation with headache, visual fatigue, poor posture, back pain, finger numbness, migraine, inadequate sleep, wrist pain or depression, which is contrary to the findings in some studies; the results were insignificant. The organization may mitigate the effect of technostress on ergonomic hazards through improving ergonomic procedures such as the provision of adjustable screens, chairs that fit table-tops, provision of chair with armrests, provision of appropriate size 
\& shape of chairs, allowing workers to take frequent breaks when tired, and mounting display screens at appropriate angles to sitting position.

It was also discovered that the less the level of technostress, the higher the performance among the auditors, showing that there is significant relationship between technostress and performance of auditors $\left(\chi^{2}=332.377 ; \mathrm{p}=0.00\right)$. It is thus important to note that reduced stress will enhance the dedication of workers within an organisation and on the overall, lead to improved performance.

The contract between employers and auditors can only be of mutual benefit to both parties if there is improved corporate attention to the working conditions of the auditors. Central among these issues is offering the auditors the relief from stress associated with improved technology usage and imperative demand for the acquisition of new knowledge on such technological facilities.

As the rate of change in information system and technology increases, the solution lies not in mere laying off of employees but in better developing human resources within the organization. This can be done through the provision of adequate training for employees before the introduction of any new technology, as suggested by majority of the auditors. If employees are forced to learn the new technology on the job, there is likelihood for them to suffer from technostress which is evident from their intensity of neck pain and inadequate sleep hazards. On the other hand, employees will be more willing to accept new technology when they have been trained on how to use such a technology, and this will in turn reduce the level of technostress. This is an important implication for management of organisations to balance office coping strategies with participation mechanism in order to avoid high levels of employee technostress.

As management continues the development of human resources as capital assets [54], auditors will increase in value relative to the organisation's investment in them.

\section{Conclusion}

This study was conducted to empirically investigate issues that might be related to the key determinants of performance among auditors in their use of technological facilities. The intent was to provide insights into organizational performance by considering the influence of technostress and ergonomic hazards as variable in the determinant of performance within audit organisations. The analysis in this study reveals that there is much difference in the way individual auditors are affected by the issues of technostress and ergonomic hazards, and how these variables impact on the organization in its entirety. In all the organizations considered on the whole, it was revealed that an insignificant relationship existed between level of technostress and performance and between ergonomic hazards and performance within audit firms, although, individual assessment gave significant relationships on some ergonomic hazards. Hence, perceptions of the technological stress on performance are still somewhat ambiguous, since some individuals can cope better than their other colleagues. It can however be concluded that overall performance can better be improved if technological facilities coping strategies and working conditions are improved within organizations. The contemporary 
global world is a very stressful one, with demands and changes to grapple with. As technology is here to stay, it is crucial that we appreciate the different responses to it, as well as fashion out adaptable ways of adjusting to it.

\section{References}

[1] Gardner, A. (2009) Combat Stress in the Workplace, Smart Pros Knowledge for Professionals, USA.

[2] Rashidi, M.Z. and Jalbani, A.A. (2009) Job Stress among Software Professionals in Pakistan: A Factor Analytic Study. Journal of Independent Studies and Research, 7, 1-16.

[3] Ungku, N.U.A., Salmiah, M.A. and Wan, K.W.I. (2010) Technostress and Organisational Commitment: A Proposed Framework. Malaysian Management Review, 45, 35-50.

[4] Tarafdar, M., Tu, Q., Ragu-Nathan, B.S. and Ragu-Nathan, T.S. (2007) The Impact of Technostress on Role Stress and Productivity. Journal of Information Management Systems, 24, 301-328. http://dx.doi.org/10.2753/MIS0742-1222240109

[5] Brod, C. (1984) Technostress: The Human Cost of the Computer Revolution. AddisonWesley Publishing Company, Reading.

[6] Champion, S. (1988) Technostress: Technology's Toll. School Library Journal, 35, 48-51.

[7] Kupersmith, J. (1998) Technostress in the Bionic Library. In: LaGuardia, C., Ed., Recreating the Academic Library: Breaking Virtual Ground, Neal-Schuman, New York, 23-47.

[8] Clark, K. and Kalin, S. (1996) Technostressed Out? How to Cope in the Digital Age. Library Journal, 121, 30-32.

[9] Weil, M.M. and Rosen, L.D. (1997) Technostress: Coping with Technology @Work @Home @Play. John Wiley \& Sons Inc, Hoboken.

[10] Tarafdar, M., Tu, Q. and Ragu-Nathan, T.S. (2011) Impact of Technostress on End-User Satisfaction and Performance. Journal of Management Information Systems, 27, 303-334. http://dx.doi.org/10.2753/MIS0742-1222270311

[11] Laudon, K.C. and Laudon, J.P. (2007) Management Information Systems: Managing the Digital Firm. 9th Edition, Pearson/Prentice Hall, Upper Saddle River, 145-278.

[12] Rosen, L.D. and Weil, M.M. (2000) Results of Our 49-Month Study of Business Attitudes Show Clerical/Support Staff, Managers and Executives Using More Technology at Work and at Home and Becoming More Hesitant toward New Technology. Byte Back Llc and Human-Ware Llc, 1-16. http://www.technostress.com/busstudy2000.htm

[13] Fletcher, B., Gowler, D. and Payne, R. (1979) Exploding the Myth of Executive Stress. Personnel Management, 11, 30-35.

[14] Cerullo, M.V. and Cerullo, M.J. (2003) Impact of SAS No. 94 on Computer Audit Techniques. Information Systems Control Journal, 1, 1-5.

[15] Dahawy, K. and Kamel, S. (2004) Information Technology in Auditing Firms in Egypt. In: Khosrow-Pour, M., Ed., Innovations through Information Technology, Idea Group Publishing, Hershey, 784-786.

[16] Ahmed, A. (2003) The Level of IT/IS Skills in Accounting Programmes in British Universities. Management Research News, 26, 20-58. http://dx.doi.org/10.1108/01409170310783709

[17] Doughty, K. and O’Driscoll, J. (2002) Information Technology Auditing and Facilitated Control Self-Assurance. Information Systems Control Journal, 4, 33-38.

[18] Bodnar, G. and Hopwood, W. (2001) Accounting Information Systems. 8th Edition, Prentice Hall, New York. 
[19] Subrahmanyam, K., Kraut, R., Greenfield, P. and Gross, E. (2000) The Impact of Home Computer Use on Children's Activities and Development. The Future of Children and Computer Technology, 10, 123-144. http://dx.doi.org/10.2307/1602692

[20] Kalia, M. (2002) Assessing the Economic Impact of Stress-The Modern Day Hidden Epidemic. Metabolism, 51, 49-53. http://dx.doi.org/10.1053/meta.2002.33193

[21] Britton, J., Day, M., Holzworth, A. and Shawcross, M. (2000) Technostress: Real Issues, Real Solutions. University of Denver, Denver.

[22] Choo, F. (1995) Auditors' Judgment Performance under Stress: A Test of the Predicted Relationship By Three Theoretical Models. Journal of Accounting, Auditing \& Finance, 10, 611-641.

[23] Rebele, J.E. and Michaels, R.E. (1990) Independent Auditors' Role Stress: Antecedent, Outcome, and Moderating Variables. Behavioral Research in Accounting, 2, 124-153.

[24] Goolsby, J.R. (1992) A Theory of Role Stress in Boundary Spanning Positions of Marketing Organizations. Journal of the Academy of Marketing Science, 20, 155-164. http://dx.doi.org/10.1007/BF02723455

[25] Kahn, R.L., Wolfe, D.M., Quinn, R.P., Snoek, J.D. and Rosenthal, R.A. (1964) Organizational Stress: Studies in Role Conflict and Ambiguity. John Wiley \& Sons Inc., Hoboken.

[26] Gill, A.S., Flaschner, A.B. and Shachar, M. (2006) Mitigating Stress and Burnout by Implementing Transformational-Leadership. International Journal of Contemporary Hospitality Management, 18, 469-481. http://dx.doi.org/10.1108/09596110610681511

[27] DeZoort, F.T. and Lord, A.T. (1997) A Review and Synthesis of Pressure Effects Research in Accounting. Journal of Accounting Literature, 16, 28-86.

[28] Khosrowpour, M. and Culpan, O. (1990) The Impact of Management Support and Education: Easing the Causality between Change and Stress in Computing Environments. Journal of Educational Technology Systems, 18, 42-53.

[29] Tu, Q., Wang, K. and Shu, Q. (2005) Computer-Related Technostress in China. Communications of the ACM, 48, 77-81. http://dx.doi.org/10.1145/1053291.1053323

[30] Tarafdar, M., Ragu-Nathan, B.S., Ragu-Nathan, T.S. and Tu, Q. (2005) Exploring the Impact of Technostress on Productivity. Proceedings of the 36th Annual Conference of Decision Sciences Institute, San Francisco, 19-22 November 2005, 13771-13776.

[31] Tiwari, T., Singh, A.L. and Singh, I.L. (2008) Information Technology-Induced Stress and Human Performance: A Critical Review. Journal of the Indian Academy of Applied Psychology, 34, 241-249.

[32] Campbell, M.C., Sheridan, J.B. and Campbell, K.Q. (1988) How Do Accountants Cope with Stress? The Woman CPA, 50, 4-7.

[33] Sweeney, J.T. and Summers, S.L. (2002) The Effect of the Busy Season Workload on Public Accountants' Job Burnout. Behavioral Research in Accounting, 14, 223-245. http://dx.doi.org/10.2308/bria.2002.14.1.223

[34] McDaniel, L.S. (1990) The Effects of Time Pressure and Audit Program Structure on Audit Performance. Journal of Accounting Research, 28, 267-285. http://dx.doi.org/10.2307/2491150

[35] Schwartz, H. and Davis, S.M. (1981) Matching Corporate Culture and Business Strategy. Organizational Dynamics, 10, 30-48. http://dx.doi.org/10.1016/0090-2616(81)90010-3

[36] Sheridan, J.E. (1992) Organizational Culture and Employee Retention. Academy of Management Journal, 35, 1036-1056. http://dx.doi.org/10.2307/256539

[37] Agboola, A.A. (2011) Towards Reducing Common Ergonomic Hazards and Alleviating Techno-Stress Associated with the Adoption of Information and Communication Tech- 
nology. International Journal of Innovation in the Digital Economy, 2, 56-65. http://dx.doi.org/10.4018/jide.2011040105

[38] Rajput, N., Gupta, M., Kesharwani, S. and Chhabra, N. (2011) Impact of Technostress in Enhancing Human Productivity: An Econometric Study. Global Journal of Enterprise Information System, 3, 5-13.

[39] Kiggundu, M.N. (1981) Task Interdependence and the Theory of Job Design. Academy of Management Review, 6, 499-508.

[40] Sharma, R. and Yetton, P. (2007) The Contingent Effects of Training, Technical Complexity, and Task Interdependence on Successful Information Systems Implementation. MIS Quarterly, 31, 219-238.

[41] Shu, Q., Tu, Q. and Wang, K. (2011) The Impact of Computer Self-Efficacy and Technology Dependence on Computer-Related Technostress: A Social Cognitive Theory Perspective. International Journal of Human-Computer Interaction, 27, 923-939. http://dx.doi.org/10.1080/10447318.2011.555313

[42] Szalma, J.L. and Hancock, P.A. (2007) Task Loading and Stress in Human-Computer Interaction: Theoretical Frameworks and Mitigation Strategies. In: Jacko, J.A. and Sears, A., Eds., Handbook for Human-Computer Interaction in Interactive Systems, 2nd Edition, Erlbaum Taylor \& Francis Group, New York, 115-132.

[43] Shepherd, S.S.G. (2004) Relationships between Computer Skills and Technostress: How Does This Affect Me? Proceedings of the 2004 ASCUE Conference, North Myrtle Beach, 6-10 June 2004, 225-231.

[44] Ragu-Nathan, T.S., Tarafdar, M., Ragu-Nathan, B.S. and Tu, Q. (2008) The Consequences of Technostress for End Users in Organizations: Conceptual Development and Empirical Validation. Information Systems Research, 19, 417-433. http://dx.doi.org/10.1287/isre.1070.0165

[45] Mahalakshmi, K. and Sornam, S.A. (2011) Ergonomics and Technostress among Library Professionals of Engineering Colleges of Anna University. Singapore Journal of Library and Information Management, 40, 89-102.

[46] Tiemo, P.A. and Ofua, J.O. (2010) Technostress: Causes, Symptoms and Coping Strategies among Librarians in University Libraries. Educational Research, 1, 713-720.

[47] Agbu, J.O. and Olubiyi, K.S. (2011) Technostress in the Age of Information Communication Technology: A Case Study of Distance Education. Educational Research, 2, 1654-1660.

[48] Otusanya, J.O. and Lauwo, S. (2010) The Role of Auditors in the Nigerian Banking Crisis. Accountancy Business and the Public Interest, 9, 159-204.

[49] Big Four Firm Performance Analysis (2011) http://www.big4.com/analysis

[50] Goodhue, D.L. (1995) Understanding User Evaluations of Information Systems. Management Science, 41, 1827-1845. http://dx.doi.org/10.1287/mnsc.41.12.1827

[51] Larson, L.L. (2001) Internal Auditor Job Burnout: An Analysis of Gender Differences. Eastern Washington University, Cheney.

[52] Takhtaei, N. and Dezfully, L.A. (2013) Impact of Gender upon the Perception and Auditor's Job Satisfaction. Asian Journal of Finance \& Accounting, 5, 355-364. http://dx.doi.org/10.5296/ajfa.v5i1.3592

[53] Mvungi, V.P., Mcharo, J., Mmbuji, M.E., Mgonja, L.E. and Kitua, A.Y. (2008) Health Hazards Related to Computer Use: Experience of the National Institute for Medical Research in Tanzania. World Academy of Science, Engineering and Technology, 48, 474-479.

[54] Weiss, D. (2000) High Performance HR: Leveraging Human Resources for Competitive Advantage. John Wiley \& Sons, Toronto. 
Submit or recommend next manuscript to SCIRP and we will provide best service for you:

Accepting pre-submission inquiries through Email, Facebook, LinkedIn, Twitter, etc. A wide selection of journals (inclusive of 9 subjects, more than 200 journals)

Providing 24-hour high-quality service

User-friendly online submission system

Fair and swift peer-review system

Efficient typesetting and proofreading procedure

Display of the result of downloads and visits, as well as the number of cited articles

Maximum dissemination of your research work

Submit your manuscript at: http://papersubmission.scirp.org/

Or contact ojbm@scirp.org 